\title{
A Paradigm Shift in Rheumatoid Arthritis over the Past Decade
}

\author{
Yuko Kaneko and Tsutomu Takeuchi
}

\begin{abstract}
Recent advances have improved our understanding of the pathogenesis of rheumatoid arthritis (RA), and the development of new therapeutics, including biological agents, have thus made it possible to strive for remission as a primary goal. Biological agents targeting a specific molecule have powerful functional capabilities, and the introduction of biological therapies has brought about revolutionary progress in RA management, culminating in a paradigm shift. There is clear evidence that a delay in treatment initiation and poor control of disease activity are associated with joint damage progression, so treatment should be started immediately after the diagnosis of RA and adapted according to disease activity as assessed by validated composite measures. In this review, we will summarize the changes in the classification and remission criteria and describe the clinical efficacies of biological agents in RA. We also discuss new promising therapies and propose future perspectives in the rheumatology field.
\end{abstract}

Key words: rheumatoid arthritis, biological agent, paradigm shift, treat-to-target

(Intern Med 53: 1895-1903, 2014)

(DOI: 10.2169/internalmedicine.53.2834)

\section{Introduction}

Rheumatoid arthritis (RA) is a chronic inflammatory disease that results in joint destruction and is associated with progressive disability and various systemic complications (1). The disease affects from $0.5-1 \%$ of adults worldwide and is more prevalent in women than in men. Recent advances in understanding the RA pathogenesis and the development of new therapeutics, including biological agents, have made it possible to aim for remission as a primary goal. Biological therapies that target a specific molecule have played one of the most important roles in this progress and brought about a paradigm shift in the RA treatment strategy. Initiating treatment as soon as possible within the so-called therapeutic "window of opportunity" has been suggested to be important (2), and disease activity should be strictly controlled to ensure successful suppression of inflammation as assessed by validated compound disease activity measures (3). In addition, new global classification criteria, remission criteria, and a treat-to-target strategy have been proposed for RA. This review describes some of the new insights, strategies, and therapeutics in the RA field.

\section{RA Pathogenesis}

RA is mainly characterized by synovial inflammation. Synovitis occurs when leukocytes infiltrate synovial compartments and involves a complex interplay between genotype and environmental triggers. The chronic phase of RA is driven by the accumulation of immune cells, such as T cells, B cells, dendritic cells, and macrophages, with positive feedback loops mediated by interactions among those cells, as well as synovial fibroblasts, chondrocytes, and osteoclasts, via cytokines and cell surface molecules (4-6). Cytokine production that arises from numerous synovial cell populations is central to RA pathogenesis. Among these cytokines, tumor necrosis factor (TNF)- $\alpha$ plays a fundamental role in inducing cytokine and chemokine expression, activating synovial fibroblasts, promoting angiogenesis, and suppressing regulatory T cells. Similarly, interleukin (IL)-6 drives local leukocyte activation and autoantibody production, promoting acute systemic effects $(7,8)$. Although those two cytokines have been the main targets of new drugs, a myriad 
Table 2. Definitions of Disease Activity Measures

\begin{tabular}{llllll}
\hline Definition & Formula & Remission & LDA & MDA & HDA \\
\hline \multirow{2}{*}{ DAS28 } & $\begin{array}{l}0.56^{*} \\
\text { SJC28+0.7*ln}(\mathrm{ESR})+0.014 * \mathrm{GH}\end{array}$ & $>2.6$ & $\leq 3.2$ & $\leq 5.1$ & $>5.1$ \\
SDAI & SJC28+TJC28+PhGA+PtGA+CRP & $\leq 3.3$ & $\leq 11$ & $\leq 26$ & $>26$ \\
CDAI & SJC28+TJC28+PhGA+PtGA & $\leq 2.8$ & $\leq 10$ & $\leq 22$ & $>22$ \\
RAPID3 & (MDHAQ+Pain VAS+PtGH)/3 & $\leq 1.0$ & $\leq 2.0$ & $\leq 4.0$ & $>4.0$ \\
\hline
\end{tabular}

CDAI: Clinical Disease Activity Index, DAS28: Disease Activity Score with 28-joint counts, ESR: erythrocyte sedimentation rate, GH: general health, HAD: high disease activity, LDA: low disease activity, MDA: moderate disease activity, MDHAQ: Multi-Dimensional Health Assessment Questionnaire, PhGA: Physician global assessment, PtGA: Patient global assessment, RAPID-3: Routine Assessment of Patient Index Data with three measures, SDAI: Simplified Disease Activity Index, SJC: swollen joint count, TJC: tender joint count, VAS: visual analog scale

Table 3. Definitions of New Remission Criteria

\begin{tabular}{|c|c|}
\hline In clinical trials & In daily practice \\
\hline \multicolumn{2}{|c|}{ Boolean-based definition } \\
\hline $\begin{array}{l}\text { At any time point, patient must satisfy all of the } \\
\text { following: } \\
\text { Tender joint count } \leq 1 \\
\text { Swollen joint count } \leq 1 \\
\text { C reactive protein } \leq 1 \mathrm{mg} / \mathrm{dL} \\
\text { Patient global assessment } \leq 1 \text { (on a } 0-10 \text { scale) }\end{array}$ & $\begin{array}{l}\text { At any time point, patient must satisfy all of the } \\
\text { following: } \\
\text { Tender joint count } \leq 1 \\
\text { Swollen joint count } \leq 1 \\
\text { Patient global assessment } \leq 1 \text { (on a } 0-10 \text { scale) }\end{array}$ \\
\hline \multicolumn{2}{|c|}{ Index-based definition } \\
\hline $\begin{array}{l}\text { At any time point, patient must have a Simplified } \\
\text { Disease Activity Index score } \leq 3.3\end{array}$ & $\begin{array}{l}\text { At any time point, patient must have a Clinical } \\
\text { Disease Activity Index score } \leq 2.8\end{array}$ \\
\hline
\end{tabular}

cal settings (30). The definitions of these indices are provided in Table 2.

\section{New remission criteria}

Although remission is an achievable goal, the definitions of RA remission differ among studies, and the attainment of this goal is strongly influenced by which set of remission criteria is applied. The widely used definition of remission based on a DAS2 8 score $<2.6$ better represents minimal disease activity than remission, as multiple joints can remain swollen or tender at that score (31-33). Therefore, the ACR and EULAR convened a joint committee to redefine RA remission; they proposed two new definitions of remission in 2011 (Table 3), both of which can be uniformly applied and are widely used in RA clinical trials (34). Although good performance has been reported for the new remission criteria, indicating that patients fulfilling the criteria tend to be free from active RA (35-37), several articles have reported that the major reason for not achieving remission based on the new definition is due to the patient global assessment (PGA), which could be influenced by non-inflammatory factors, including low back pain, fatigue, and fibromyalgia $(38,39)$. The validity of the criteria is still being discussed.

\section{Treat-to-target for $\mathbf{R A}$}

\section{Importance of tight control}

"Tight control," in which patients are treated to specified targets with aggressive therapy if necessary, results in beneficial outcomes outside the field of rheumatology. For example, a low glycated hemoglobin (HbA1c) level is widely recognized to a goal in counseling visits because achieving a threshold is understood to drive long-term outcomes in DM $(40,41)$. Similar procedures are used to avoid future organ damage in the treatment of hypertension, hyperlipidemia, and other conditions. In patients with RA, several clinical trials have demonstrated the advantages of tight control (42-48), thus showing that strategy-driven arms have significantly better results with regard to disease activity, as well as in functional outcomes and radiographic endpoints, when disease activity was taken into account when adjusting treatment.

\section{Treat-to-target for RA}

In the context of new developments and accumulating evidence for RA treatments, a task force of rheumatologists and patients with RA developed a set of recommendations on the basis of evidence derived from a systematic literature 


\section{Table 4. Recommendations Proposed in Treat-to-Target Task Force}
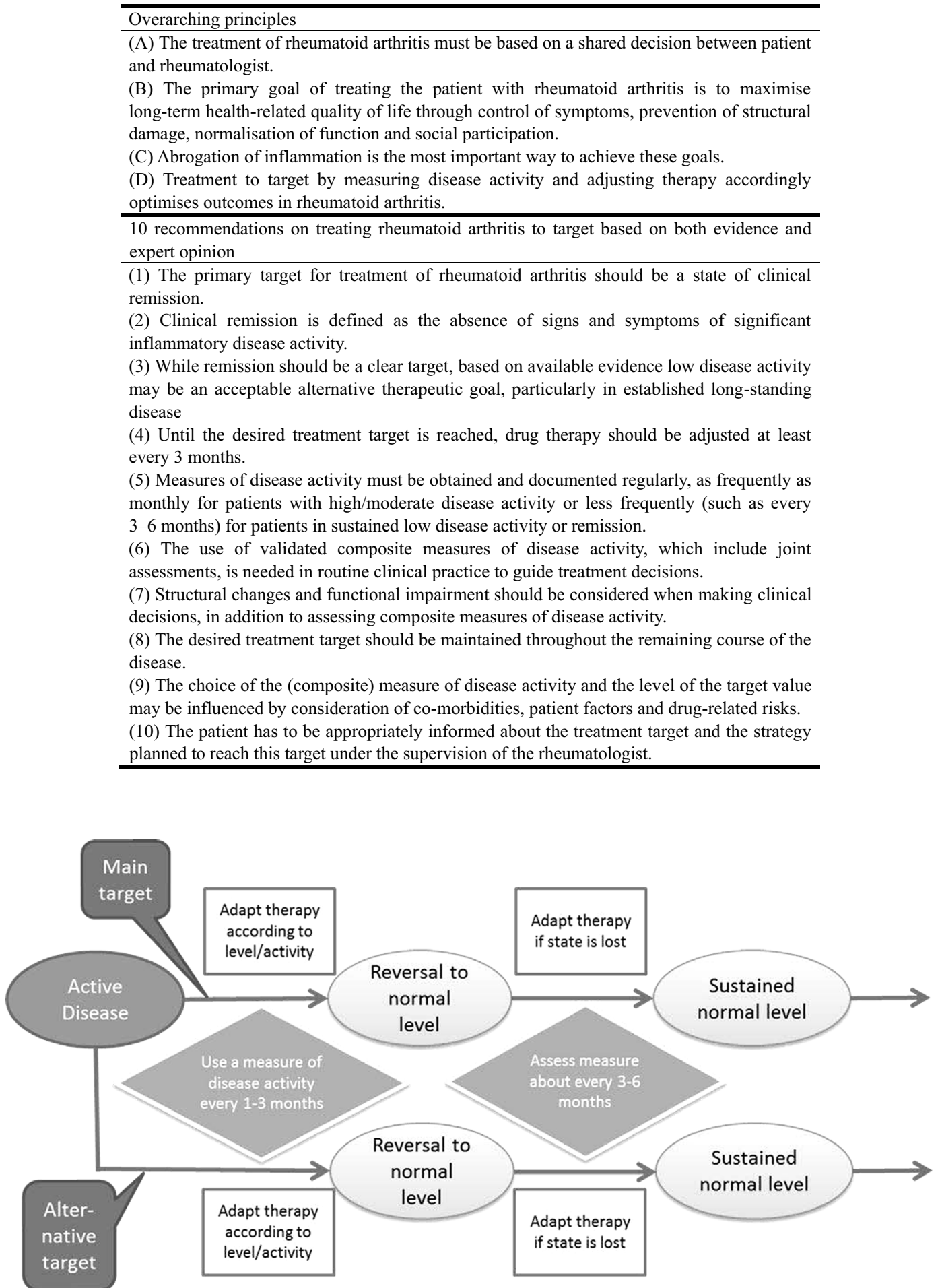

Figure 1. Generic algorithm for T2T in RA. The main targets of remission and low disease activity are shown separately, but the approaches to attain the targets and sustain them are essentially identical.

review and expert opinion. The treat-to-target (T2T) activity resulted in four overarching principles and 10 recommendations (Table 4), which were published in 2011 (49). The 10 recommendations are supposed to inform patients, rheumatologists, and other stakeholders about strategies for reaching optimal outcomes in RA. The T2T recommendations suggest adapting therapy if no improvement occurs within three months or if the treatment target, which is defined as remission in early RA and at least low disease activity in established RA, is not attained within six months (Fig. 1). The $\mathrm{T} 2 \mathrm{~T}$ recommendations do not deal with any particular type of drug or groups of agents and are importantly generic so that an optimal outcome can be sought irrespective of the availability of specific drugs. An anonymous survey of more 
Table 5. Characteristics of Seven Biological Agents Available for Rheumatoid Arthritis in Japan

\begin{tabular}{|c|c|c|c|c|c|c|c|}
\hline Biological agents & Infliximab & Etanercept & Adalimumab & Tocilizumab & Abatacept & Golimumab & Certolizumab \\
\hline Approved year & 2003 & 2005 & 2008 & 2008 & 2010 & 2012 & 2013 \\
\hline Target & $\mathrm{TNF} \alpha$ & $\mathrm{TNF} \alpha, \mathrm{LT} \alpha$ & $\mathrm{TNF} \alpha$ & IL-6 & $\mathrm{CD} 80 / 86$ & $\mathrm{TNF} \alpha$ & $\mathrm{TNF} \alpha$ \\
\hline Structure & $\begin{array}{l}\text { chimeric } \\
\text { antibody }\end{array}$ & $\begin{array}{l}\text { TNF } \\
\text { receptor/Ig } \\
\text { G-Fc fusion }\end{array}$ & $\begin{array}{l}\text { fully human } \\
\text { antibody }\end{array}$ & $\begin{array}{l}\text { humanized } \\
\text { antibody }\end{array}$ & $\begin{array}{l}\text { CTLA4/IgG- } \\
\text { Fc fusion }\end{array}$ & $\begin{array}{l}\text { fully human } \\
\text { antibody }\end{array}$ & $\begin{array}{l}\text { polyethylene } \\
\text { glycol-modified } \\
\text { Fab' fragment }\end{array}$ \\
\hline Administration route & IV & $\mathrm{SC}$ & $\mathrm{SC}$ & IV, SC & IV, SC & $\mathrm{SC}$ & $\mathrm{SC}$ \\
\hline Half time period (day) & $8-10$ & $3-5$ & $9-16$ & $\begin{array}{l}4-7 \text { (IV) } \\
1-2(\mathrm{SC})\end{array}$ & $\begin{array}{l}9(\mathrm{IV}) \\
13(\mathrm{SC})\end{array}$ & $10-14$ & $11-13$ \\
\hline Anti-drug antibody* (with MTX) (\%) & $4.1-27.3$ & NA & 19.3 & NA & $\begin{array}{l}0-3.0 \text { (IV) } \\
1.1(\mathrm{SC})\end{array}$ & 0 & $1.2-8.2$ \\
\hline (without MTX) (\%) & NA & NA & 44.0 & $\begin{array}{l}0-3.0(\mathrm{IV}) \\
3.5-18.0(\mathrm{SC})\end{array}$ & NA & $3.3-4.0$ & $10.8-29.9$ \\
\hline Dose (mg) & $3-10 / \mathrm{kg}$ & $10-50$ & $40-80$ & $\begin{array}{l}8 / \mathrm{kg}(\mathrm{IV}) \\
162(\mathrm{SC})\end{array}$ & $\begin{array}{l}500-750(\mathrm{IV}) \\
125(\mathrm{SC})\end{array}$ & $50-100$ & 400 \\
\hline Administration interval (week) & $4-8$ & $0.5-1$ & 2 & $\begin{array}{l}4(\mathrm{IV}) \\
2(\mathrm{SC})\end{array}$ & $\begin{array}{l}4(\mathrm{IV}) \\
1(\mathrm{SC}) \\
\end{array}$ & 4 & 4 \\
\hline
\end{tabular}

than 1,500 rheumatologists on their agreement with the T2T recommendations revealed a very high level of agreement with every item, achieving more than a mean 8.4 points on a 0 to 10 point scale (50). However, such agreement does not necessarily mean that these physicians have implemented the recommendations in their practice. As with every set of recommendations, there are barriers regarding application in practice, mainly because of time or resource constraints (51). Overall, the T2T concept has become widely applicable and is commonly used in clinical practice. Hopefully, it will ultimately provide significant benefits to patients with RA.

\section{New Therapeutics Based on RA Pathogenesis}

\section{Biological agents targeting cytokines}

Beyond the development of new classification criteria and strategies for RA, there has been great progress in the development of therapeutics based on growing insights into the pathogenesis of RA. Currently, seven biological agents targeting cytokines or cell-surface molecules are available for RA in Japan. Considerable efforts have been made to develop effective and safe drugs, and these biological agents have several distinct characteristics, including the target (TNF, IL-6, or CD80/86), structural type (monoclonal antibodies, receptors/ligands fused to the Fc portion of IgG, or polyethylene glycol-modified humanized Fab' fragment), and the extent of humanization (chimeric, humanized, or fully human) (Table 5). Several multi-center, randomized, double-blind clinical trials of biologics have been conducted in Japan (52-56), and these compounds achieved excellent ACR20 responses in patients who had an inadequate response to methotrexate or disease-modifying antirheumatic drugs (DMARDs) (Fig. 2). Clinical remission occurred in approximately $20-45 \%$ of Japanese RA patients in the clinical trials and studies, implying that clinical remission is a realistic treatment goal (57-60). These studies also demonstrated that functional impairment, as assessed by Health Assessment Questionnaire (HAQ), was significantly improved with biologic treatment. Moreover, in a Japanese trial of tocilizumab (61), increases in the total Sharp score (TSS) and its components and the erosion and joint narrowing scores were significantly lower with tocilizumab monotherapy than in DMARD therapy, providing the first evidence that biologics are superior to DMARDs for inhibiting structural damage. Subsequent clinical trials and studies of other biologic agents with methotrexate revealed a striking inhibition of structural damage, indicating that joint damage in RA can be attenuated (61-67) (Fig. 3). A number of reports have described the long-time effectiveness of biologic treatment from two to as long as eight years. Although treatment regimens vary, it has been shown that early and maintained targeted treatment using biologic agents has functional and radiological benefits (68-70).

\section{Biologic agent safety}

While the effectiveness of biologic agents has been well established, their safety continues to be scrutinized. In Japan, post marketing surveillance (PMS) on all available biologic agents has been conducted. PMS data have been collected on all patients with RA who received biologic agents in Japan since 2003, and those reports have revealed the exact frequencies of drug-related adverse events (especially opportunistic infections, such as tuberculosis and pneumocystis jirovecii) and factors that affect drug safety and effectiveness in clinical practice. PMS for infliximab, etanercept, adalimumab, and tocilizumab were recently completed and published (71-74). The primary risk factors associated with serious infection were older age ( $\geq 60$ or 65 ), concomitant glucocorticoid use, physical functional impairment, and existing lung disease. These data have made it possible to manage RA patients on a biologic agent more safely. 


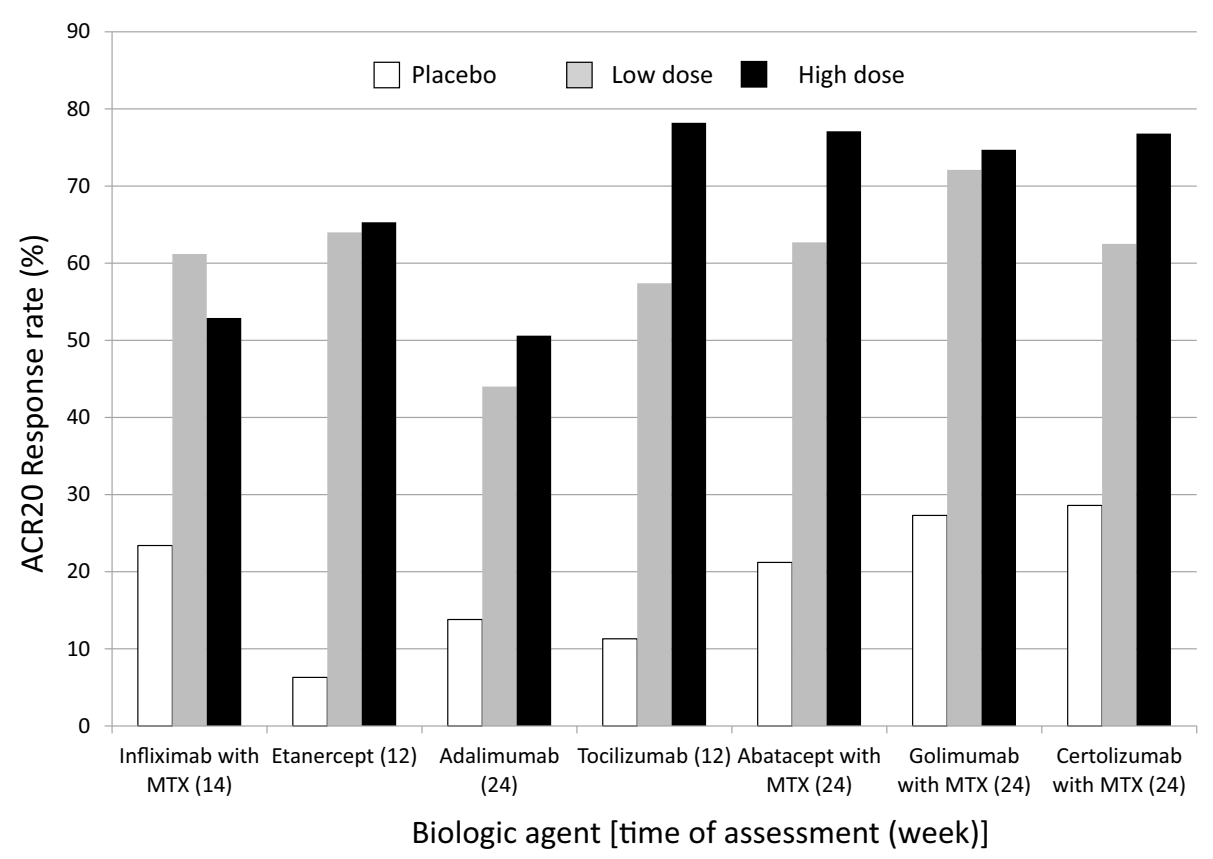

Figure 2. Efficacy of biological agents on the clinical response in Japanese RA patients. MTX: methotrexate

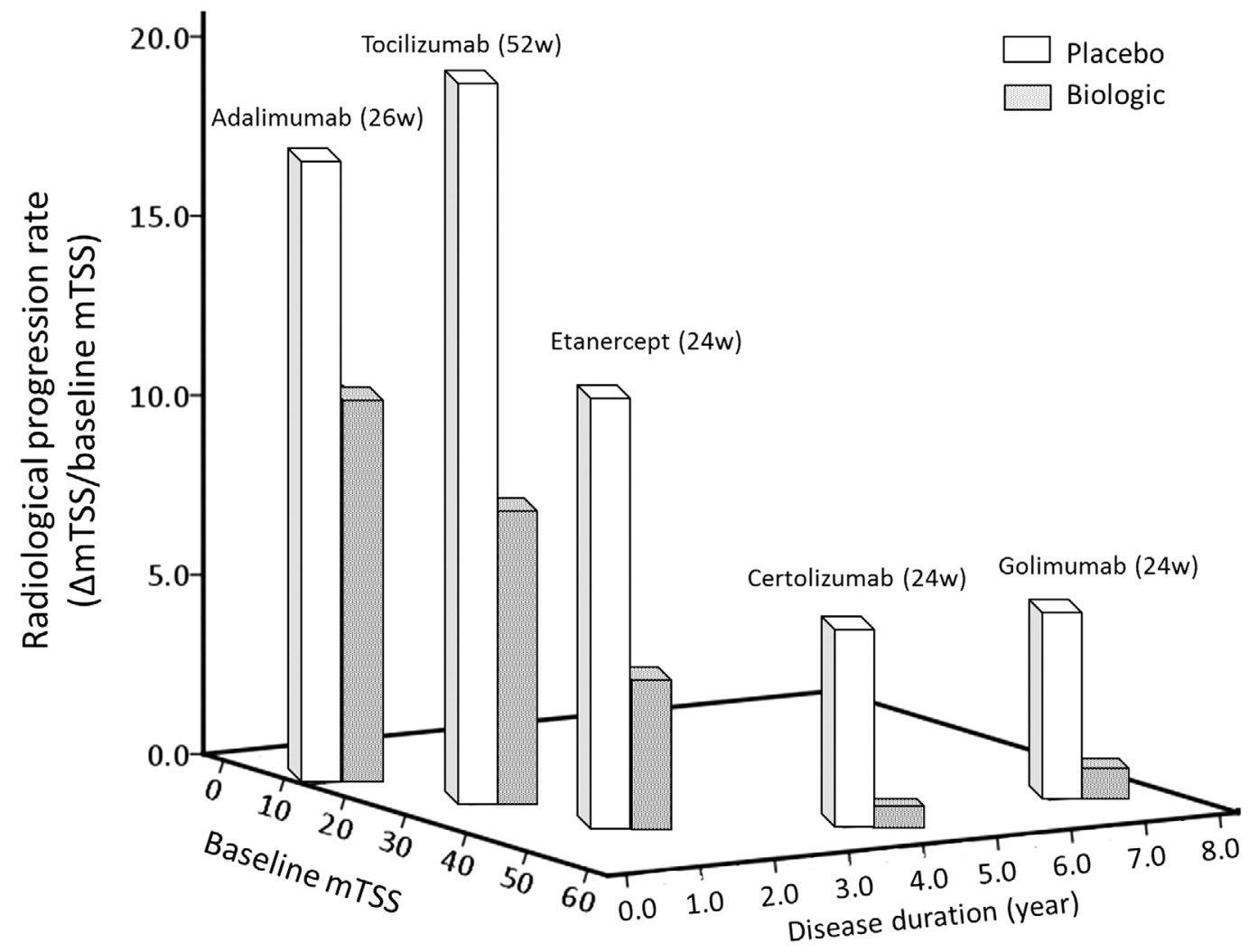

Figure 3. Efficacy of biological agents on the inhibition of radiological progression in Japanese RA patients. The radiological progression rates ( $\triangle \mathrm{mTSS} / \mathrm{baseline} \mathrm{mTSS})$ for each biological agent were compared to the placebo used in the clinical trials. 


\section{Further developments in therapeutics}

Elucidation of the complex intracellular signaling molecules that regulate cytokines and their receptor-mediated functions is facilitating the development of specific smallmolecule inhibitors. The Janus kinase (JAK) 1 and 3 inhibitor tofacitinib was recently approved for use in Japan, Russia, and the U.S. Efforts to develop novel biological agents to target other cytokines and intracellular signaling pathways, such as IL-17, B-lymphocyte stimulator (BLys), a proliferation-inducing ligand (APRIL), granulocytemacrophage colony-stimulating factor (GM-CSF), JAK 1 and 2, and spleen tyrosine kinase (Syk), are ongoing. The range of available therapeutics is expected to continue to expand.

\section{Conclusion}

Significant advances have greatly improved the lives of patients with RA, and it can be said that a paradigm shift has occurred over the last decade. However, important problems remain to be solved, such as persistent synovitis despite intensive treatment and the adverse effects of biological agents. Attention should therefore be paid to differences among patients, and RA treatment should ultimately be individualized to each patient's needs to maximize drug efficacy and minimize any associated risks.

\section{Author's disclosure of potential Conflicts of Interest (COI).} Tsutomu Takeuchi: Advisory role, Astra Zeneca K.K., Eli Lilly Japan K.K., Novartis Pharma K.K., Mitsubishi Tanabe Pharma Co., Asahi Kasei Medical K.K., AbbVie GK, and Daiichi Sankyo Co.,Ltd.; Honoraria, Abbott Japan Co., Ltd., Bristol-Myers K.K., Chugai Pharmaceutical Co,. Ltd., Eisai Co., Ltd., Janssen Pharmaceutical K.K., Mitsubishi Tanabe Pharma Co., Pfizer Japan Inc., Takeda Pharmaceutical Co., Ltd., Astellas Pharma, and Daiichi Sankyo Co.,Ltd.; Research funding, Abbott Japan Co., Ltd., Astellas Pharma, Bristol-Myers K.K., Chugai Pharmaceutical Co, Ltd., Daiichi Sankyo Co., Ltd., Eisai Co., Ltd., Janssen Pharmaceutical K.K., Mitsubishi Tanabe Pharma Co., Pfizer Japan Inc., Sanofi-Aventis K.K., Santen Pharmaceutical Co., Ltd., Takeda Pharmaceutical Co., Ltd., Teijin Pharma Ltd., AbbVie GK, Asahikasei Pharma Corp., and Taisho Toyama Pharmaceutical Co., Ltd.

\section{References}

1. Firestein GS. Evolving concepts of rheumatoid arthritis. Nature 423: 356-361, 2003.

2. van Nies JA, Krabben A, Schoones JW, Huizinga TW, Kloppenburg M, van der Helm-van Mil AH. What is the evidence for the presence of a therapeutic window of opportunity in rheumatoid arthritis? A systematic literature review. Ann Rheum Dis 73: 861870, 2014.

3. Scholes M, Smolen JS. Treating rheumatoid arthritis to target: Evidence-based recommendations for enhanced disease management. Reumatol Clin 8: 1-2, 2012.
4. McInnes IB, Schett G. The pathogenesis of rheumatoid arthritis. N Engl J Med 365: 2205-2219, 2011.

5. Szekanecz Z, Pakozdi A, Szentpetery A, Besenyei T, Koch AE. Chemokines and angiogenesis in rheumatoid arthritis. Front Biosci (Elite Ed) 1: 44-51, 2009.

6. Polzer K, Baeten D, Soleiman A, et al. Tumour necrosis factor blockade increases lymphangiogenesis in murine and human arthritic joints. Ann Rheum Dis 67: 1610-1616, 2008.

7. Feldmann M, Brennan FM, Maini RN. Rheumatoid arthritis. Cell 85: 307-310, 1996.

8. Hess A, Axmann R, Rech J, et al. Blockade of TNF- $\alpha$ rapidly inhibits pain responses in the central nervous system. Proc Natl Acad Sci USA 108: 3731-3736, 2011.

9. Finckh A, Liang MH, van Herckenrode CM, et al. Long-term impact of early treatment on radiographic progression in rheumatoid arthritis: a meta-analysis. Arthritis Rheum 55: 864-872, 2006.

10. Boers M. Understanding the window of opportunity concept in early rheumatoid arthritis. Arthritis Rheum 48: 1771-1774, 2003.

11. Amjadi S, Khanna D, Park GS, et al. Dating the "window of therapeutic opportunity" in early rheumatoid arthritis: accuracy of patient recall of arthritis symptom onset. J Rheumatol 31: 16861692, 2004.

12. Singh JA, Furst DE, Bharat A, et al. 2012 Update of the 2008 American College of Rheumatology recommendations for the use of disease-modifying antirheumatic drugs and biologic agents in the treatment of rheumatoid arthritis. Arthritis Care Res 64: 625639, 2012.

13. Smolen JS, Landewé R, Breedveld FC, et al. EULAR recommendations for the management of rheumatoid arthritis with synthetic and biological disease-modifying antirheumatic drugs: 2013 update. Ann Rheum Dis 73: 492-509, 2014.

14. Arnett FC, Edworthy SM, Bloch DA, McShane DJ, Fries JF, et al. The America Rheumatism Association 1987 revised criteria for the classification of rheumatoid arthritis. Arthritis Rheum 31: 315-324, 1987.

15. Banal F, Dougados M, Combescure C, Gossec L. Sensitivity and specificity of the American College of Rheumatology 1987 criteria for the diagnosis of rheumatoid arthritis according to disease duration: a systematic literature review and meta-analysis. Ann Rheum Dis 68: 1184-1191, 2009.

16. Aletaha D, Neogi T, Silman A, et al. 2010 Rheumatoid arthritis classification criteria: an America college of rhuematology/european league against rheumatism collaborative initiative. Ann Rheum Dis 69: 1580-1588, 2010.

17. Funovits J, Aletaha D, Bykerk V, et al. The 2010 American college of rheumatology/european league against rheumatism classification criteria for rheumatoid arthritis: methodological report phase I. Ann Rheum Dis 69: 1589-1595, 2010.

18. Neogi T, Aletaha D, Silman AJ, et al. The 2010 American college of rheumatology/european league against rheumatism classification criteria for rheumatoid arthritis: Phase 2 methodological report. Arthritis Rheum 62: 2582-2591, 2010.

19. Cader MZ, Filer A, Hazlehurst J, de Pablo P, Buckley CD, et al. Performance of the 2010 ACR/EULAR criteria for rheumatoid arthritis:comparison with the 1987 ACR criteria in a very early synovitis cohort. Ann Rheum Dis 70: 949-955, 2011.

20. Kaneko Y, Kuwana M, Kamed H, Takeuchi T. Sensitivity and specificity of 2010 rheumatoid arthritis classification criteria. Rheumatology (Oxford) 50: 1268-1274, 2010.

21. Alves C, Luime JJ, van Zeben D, et al. Diagnostic performance of the ACR/EULAR 2010 criteria for rheumatoid arthritis and two diagnostic algorithms in an early arthritis clinic (REACH). Ann Rheum Dis 70: 1645-1647, 2011.

22. Britsemmer K, Ursum J, Gerritsen M, van Tuyl L, van Schaardenburg D. Validation of the 2010 ACR/EULAR classification criteria for rheumatoid arthritis: slight improvement over the 1987 ACR 
criteria. Ann Rheum Dis 70: 1468-1470, 2011.

23. Kawashiri SY, Suzuki T, Okada A, et al. Musculoskeletal ultrasonography assists the diagnostic performance of the 2010 classification criteria for rheumatoid arthritis. Mod Rheumatol 23: 3643, 2011.

24. van der Linden MM, Knevel R, Huizinga TWJ, van der Helm-van Mil AHM. Classification of rheumatoid arthritis. Comparison of the 1987 America College of Rheumatology criteria and the 2010 American College of Rheumatology/American League Against Rheumatism Criteria. Arthritis Rheum 63: 37-42, 2011.

25. Sakellariou G, Sciré CA, Zambon A, Caporali R, Montecucco C. Performance of the 2010 classification criteria for rheumatoid arthritis: a systematic literature review and a meta-analysis. PLoS One 8: e56528, 2013.

26. Emery P, Salmon M. Early rheumatoid arthritis: time to aim for remission? Ann Rheum Dis 54: 944-947, 1995.

27. Smolen JS, Aletaha D. What should be our treatment goal in rheumatoid arthritis today? Clin Exp Rheumatol 24 (Suppl 43): S-7-S13, 2006.

28. Pincus T, Gibofsky A, Weinblatt ME. Urgent care and tight control of rheumatoid arthritis as in diabetes and hypertension: better treatments but a shortage of rheumatologists. Arthritis Rheum 46: 851-854, 2002.

29. Lansbury J. Quantitation of the activity of rheumatoid arthritis. 5. A method for summation of the systemic indices of rheumatoid activity. Am J Med Sci 232: 300-310, 1956.

30. Anderson J, Caplan L, Yazdany J, et al. Rheumatoid arthritis disease activity measures: American college of rheumatology recommendations for use in clinical practice. Arthritis Care Res (Hoboken) 64: 640-647, 2012.

31. van der Heijde D, Klareskog L, Boers M, et al. Comparison of different definitions to classify remission and sustained remission: 1 year TEMPO results. Ann Rheum Dis 64: 1582-1587, 2005.

32. Mäkinen $H$, Kautiainen $H$, Hannonen $P$, et al. Is DAS28 an appropriate tool to assess remission in rheumatoid arthritis? Ann Rheum Dis 64: 1410-1413, 2005.

33. Landewé R, van der Heijde D, van der Linden S, et al. Twentyeight-joint counts invalidate the DAS28 remission definition owing to the omission of the lower extremity joints: a comparison with the original DAS remission. Ann Rheum Dis 65: 637-641, 2006.

34. Felson DT, Smolen JS, Wells G, et al. American college of rheumatology/european league against rheumatism provisional definition of remission in rheumatoid arthritis for clinical trials. Ann Rheum Dis 70: 404-413, 2011.

35. Thiele K, Huscher D, Bischoff S, et al. Performance of the 2011 ACR/EULAR preliminary remission criteria compared with DAS 28 remission in unselected patients with rheumatoid arthritis. Ann Rheum Dis 72: 1194-1199, 2013.

36. Zhang B, Combe B, Rincheval N, Felson DT. Validation of ACR/ EULAR definition of remission in rheumatoid arthritis from RA practice: the ESPOIR cohort. Arthritis Res Ther 14: R156, 2012.

37. Kaneko Y, Kondo H, Takeuchi T. American college of rheumatology/european league against rheumatism remission criteria for rheumatoid arthritis maintain reliable performance when evaluated in 44 joints. J Rheumatol 40: 1254-1258, 2013.

38. Masri KR, Shaver TS, Shahouri SH, et al. Validity and Reliability Problems with Patient Global as a Component of the ACR/EULAR Remission Criteria as Used in Clinical Practice. J Rheumatol 39: 1139-1145, 2012.

39. Vermeer M, Kuper HH, van der Bijl AH, et al. The provisional ACR/EULAR definition of remission in RA: a comment on the patient global assessment criterion. Rheumatology (Oxford) 51: 1076-1080, 2012.

40. Havas S, Donner T. Tight control of type 1 diabetes: recommendations for patients. Am Fam Physician 74: 971-978, 2006.

41. Diabetes Control and Complications Trial (DCCT) Research
Group. Effect of intensive diabetes management on macrovascular events and risk factors in the Diabetes Control and Complications Trial. Am J Cardiol 75: 894-903, 1995.

42. Schoels M, Knevel R, Aletaha D, et al. Evidence for treating rheumatoid arthritis to target: results of a systematic literature search. Ann Rheum Dis 69: 638-643, 2010.

43. Fransen J, Bernelot Moens H, Speyer I, Van Riel PL. Effectiveness of systematic monitoring of rheumatoid arthritis disease activity in daily practice: a multicenter, cluster randomised control trial. Ann Rheum Dis 64: 1294-1298, 2005.

44. Grigor C, Capell H, Stirling A, et al. Effect of a treatment strategy of tight control for rheumatoid arthritis (the TICORA study): a single-blind randomised controlled trial. Lancet 364: 263-269, 2004.

45. Stenger AA, Van Leeuwen MA, Houtman PM, et al. Early effective suppression of inflammation in rheumatoid arthritis reduces radiographic progression. Br J Rheumatol 37: 1157-1163, 1998.

46. Verstappen SM, Jacobs JW, van der Veen MJ, et al. Intensive treatment with methotrexate in early rheumatoid arthritis: aiming for remission. Computer Assisted Management in Early Rheumatoid Arthritis (CAMERA, an open-label strategy trial). Ann Rheum Dis 66: 1443-1449, 2007.

47. Van Tuyl LH, Lems WF, Voskuyl AE, et al. Tight control and intensifi ed COBRA combination treatment in early rheumatoid arthritis: $90 \%$ remission in a pilot trial. Ann Rheum Dis 67: 15741577, 2008.

48. Edmonds J, Lassere M, Sharp JT. Objectives study in RA (OSRA): a RCT defining the best clinical target for disease activity control in RA. Ann Rheum Dis 66 (Suppl II): 325, 2007.

49. Smolen JS, Aletaha D, Bijlsma JW, et al. Treating rheumatoid arthritis to target: recommendations of an international task force. Ann Rheum Dis 69: 631-637, 2010.

50. Hanoui B, Smolen JS, Aletaha D, et al. Treating rheumatoid arthritis to target:multinational recommendations assessment questionnaire. Ann Rheum Dis 70: 1999-2002, 2011.

51. Haraoui B, Bensen W, Bessette L, et al. Treating rheumatoid arthritis to target: a Canadian physician survey. J Rheumatol 39: 949-953, 2012.

52. Takeuchi $T$, Kameda $H$. The Japanese experience with biologic therapies for rheumatoid arthritis. Nat Rev Rheumatol 6: 644-652, 2010.

53. Abe T, Takeuchi T, Miyasaka N. A multicenter, double-blind, randomized, placebo controlled trial of infliximab combined with low dose methotrexate in Japanese patients with rheumatoid arthritis. J. Rheumatol 33: 37-44, 2006.

54. Nishimoto N, Yoshizaki K, Miyasaka N, et al. Treatment of rheumatoid arthritis with humanized anti-interleukin-6 receptor antibody: a multicenter, double-blind, placebo-controlled trial. Arthritis Rheum 50: 1761-69, 2004.

55. Miyasaka N, Investigators TC. Clinical investigation in highly disease-affected rheumatoid arthritis patients in Japan with adalimumab applying standard and general evaluation: the CHANGE study. Mod. Rheumatol 18: 252-262, 2008.

56. Takeuchi T, Matsubara T, Nitobe $T$, et al. Phase II dose-response study of abatacept in Japanese patients with active rheumatoid arthritis with an inadequate response to methotrexate. Mod Rheumatol 23: 226-235, 2013.

57. Yamanaka H, Tanaka Y, Sekiguchi N, et al. Retrospective clinical study on the notable efficacy and related factors of infliximab therapy in a rheumatoid arthritis management group in Japan (RECONFIRM). Mod Rheumatol 17: 28-32, 2008.

58. Tanaka $Y$, Takeuchi $T$, Inoue $E$, et al. Retrospective clinical study on the notable efficacy and related factors ofinfliximab therapy in a rheumatoid arthritis management group in Japan: One-year clinical and radiographic outcomes (RECONFIRM-II). Mod Rheumatol 18: 146-152, 2008. 
59. Takeuchi T, Tanaka Y, Amano K, et al. Clinical, radiographic and functional effectiveness of tocilizumab for rheumatoid arthritis patients--REACTION 52-week study. Rheumatology (Oxford) 50: 1908-1915, 2011

60. Takeuchi T, Tanaka Y, Kaneko Y, et al. Effectiveness and safety of adalimumab in Japanese patients with rheumatoid arthritis: retrospective analyses of data collected during the first year of adalimumab treatment in routine clinical practice (HARMONY study). Mod Rheumatol 22: 327-338, 2012.

61. Nishimoto N, Hashimoto J, Miyasaka N, et al. Study of active controlled monotherapy used for rheumatoid arthritis, an IL-6 inhibitor (SAMURAI): evidence of clinical and radiographic benefit from an $\mathrm{x}$ ray reader-blinded randomised controlled trial of tocilizumab. Ann Rheum Dis 66: 1162-1167, 2007.

62. Takeuchi T, Miyasaka N, Inoue $\mathrm{T}$, et al. Impact of trough serum level on radiographic and clinical response to infliximab plus methotrexate in patients with rheumatoid arthritis: results from the RISING study. Mod Rheumatol 19: 478-487, 2009.

63. Lipsky PE, van der Heijde E, St Clair WD, et al. Infliximab and methotrexate in the treatment of rheumatoid arthritis. Anti-Tumor Necrosis Factor Trial in Rheumatoid Arthritis with Concomitant Therapy Study Group. N Engl J Med 343: 1594-1602, 2000.

64. Takeuchi T, Miyasaka N, Zang C, et al. A phase 3 randomized, double-blind, multicenter comparative study evaluating the effect of etanercept versus methotrexate on radiographic outcomes, disease activity, and safety in Japanese subjects with active rheumatoid arthritis. Mod Rheumatol 23: 623-633, 2013.

65. Tanaka Y, Harigai M, Takeuchi T, et al. Golimumab in combination with methotrexate in Japanese patients with active rheumatoid arthritis: results of the GO-FORTH study. Ann Rheum Dis 71: 817-824, 2012.

66. Takeuchi $\mathrm{T}$, Yamanaka $\mathrm{H}$, Ishiguro $\mathrm{N}$, et al. Adalimumab, a human anti-TNF monoclonal antibody, outcome study for the prevention of joint damage in Japanese patients with early rheumatoid arthritis: the HOPEFUL 1 study. Ann Rheum Dis 73: 536-543, 2014.

67. Yamamoto K, Takeuchi T, Yamanaka H, et al. Efficacy and safety of certolizumab pegol plus methotrexate in Japanese rheumatoid arthritis patients with an inadequate response to methotrexate: the J-RAPID randomized, placebo-controlled trial. Mod Rheumatol (in press).

68. van den Broek M, Lems WF, Allaart CF. BeSt practice: the success of early-targeted treatment in rheumatoid arthritis. Clin Exp Rheumatol 30 (Suppl 73): S35-S38, 2012.

69. Bejarano V, Conaghan PG, Quinn MA, Saleem B, Emery P. Benefits 8 years after a remission induction regime with an infliximab and methotrexate combination in early rheumatoid arthritis. Rheumatology(Qxford) 49: 1971-1974, 2009.

70. Vander Cruyssen B, Durez P, Westhovens R, De Keyser F. Sevenyear followup of infliximab therapy in rheumatoid arthritis patients with severe longstanding refractory disease: attrition rate and evolution of disease activity. Arthritis Res Ther 12: R77, 2010.

71. Takeuchi T, Tatsuki Y, Nogami Y, et al. Postmarketing surveillance of the safety profile of infliximab in 5000 Japanese patients with rheumatoid arthritis. Ann Rheum Dis 67: 189-194, 2008.

72. Koike T, Harigai M, Inokuma S, et al. Postmarketing surveillance of the safety and effectiveness of etanercept in Japan. J Rheumatol 36: 898-906, 2009.

73. Koike T, Harigai M, Ishiguro N, et al. Safety and effectiveness of adalimumab in Japanese rheumatoid arthritis patients: Postmarketing surveillance report of 7740 patients. Mod Rheumatol (in press).

74. Koike T, Harigai M, Inokuma $S$, et al. Effectiveness and safety of tocilizumab: postmarketing surveillance of 7901 patients with rheumatoid arthritis in Japan. J Rheumatol 41: 15-23, 2014.

(C) 2014 The Japanese Society of Internal Medicine http://www.naika.or.jp/imonline/index.html 